\title{
Challenging Easter Island's collapse: the need for interdisciplinary synergies
}

\author{
Valentí Rull ${ }^{1}$, Núria Cañellas-Boltà ${ }^{1,2}$, Alberto Sáez ${ }^{2}$, Olga Margalef ${ }^{2}$, Roberto Bao ${ }^{3}$, \\ Sergi Pla-Rabes ${ }^{4,5}$, Blas Valero-Garcés ${ }^{6}$ and Santiago Giralt ${ }^{7}$ \\ ${ }^{1}$ Botanic Institute of Barcelona (IBB-CSIC-ICUB), Barcelona, Spain \\ ${ }_{2}$ Department of Stratigraphy, Paleontology and Marine Sciences, Faculty of Geology, Universitat de Barcelona, Barcelona, Spain \\ ${ }^{3}$ Department of Geology, Faculty of Sciences, Universidade da Coruña, A Coruña, Spain \\ ${ }^{4}$ Center for Advanced Studies of Blanes (CEAB-CSIC), Blanes, Girona, Spain \\ ${ }^{5}$ Centre for Ecological Research and Forestry Applications (CREAF), Barcelona, Spain \\ ${ }^{6}$ Pyrenean Institute of Ecology (IPE-CSIC), Zaragoza, Spain \\ 7 Department of Sedimentary Geology and Geohazadrs, Institute of Earth Sciences Jaume Almera (ICTJA-CSIC), Barcelona, Spain
}

Edited by:

Christopher Carcaillet, Ecole

Pratique des Hautes Etudes, France

Reviewed by:

Christopher Carcaillet, Ecole

Pratique des Hautes Etudes, France

Simon C. Brewer, University of

Utah, USA

\section{*Correspondence:}

Valentí Rull, Laboratory of

Palynology and Paleoecology,

Botanic Institute of Barcelona

(IBB-CSIC-ICUB), Pg. del Migdia s/n,

Barcelona 08038, Spain

e-mail:vrull@ibb.csic.es
The reigning paradigm holds that Easter Island suffered a socio-ecological collapse (ecocidal or not) sometime in the last millennium, prior to European contact (AD 1720). We discuss some novel paleoecological and archaeological evidence that challenges this assumption. We use this case study to propose a closer collaboration between archaeology and paleoecology. This collaboration allows us to unravel historical trends in which both environmental changes and human activities might have acted, alone or coupled, as drivers of ecological and social transformations. We highlight a number of particular points in which scholars from disparate disciplines, working together, may enhance the scope and the soundness of historical inferences. These points are the following: (1) the timing of the initial Easter Island colonization and the origin of the settlers, (2) the pace of ecological and social transformations since that time until the present, and (3) the occurrence of potential climate-human synergies as drivers of socio-ecological shifts.

Keywords: Easter Island, ecological breakdown, social collapse, paleoecology, paleoclimatology, research synergies

\section{INTRODUCTION}

Currently, Easter Island (Rapa Nui, in the indigenous language) is almost totally covered by extensive grasslands spotted with small planted forests of recently introduced trees, mostly Eucalyptus, and shrubs (Etienne et al., 1982; Zizka, 1991). However, pollen diagrams spanning the last ca. 30,000 years show a different ecological scenario wherein palm-dominated forests would have occupied most of the island (Flenley and King, 1984; Flenley et al., 1991). Current prevailing thought argues that an outstanding ecological shift occurred in a more or less abrupt manner approximately one millennium ago (prior to European contact in $\mathrm{AD}$ 1720). This shift, presumably linked to the overexploitation of natural resources by humans (including deforestation), would have led to natural resource exhaustion and social collapse. The potential contribution of agents other than human activities (e.g., climatic and other environmental changes) to the ecological shift was explicitly dismissed (Flenley and Bahn, 2003). The assumed socio-ecological collapse has established itself as a paradigm for Easter Island and has been presented as an ecocide and a microcosmic model of the potential consequences of current management practices at a global level (Diamond, 2005). This view has received extensive media coverage and influenced public opinion. Other authors agree with the occurrence of the socio-ecological catastrophe but disagree with its assumed ecocidal character (e.g., Hunt and Lipo, 2010).
As research progresses and new empirical observations are made, initial frameworks may require some modifications and even reconsiderations. In the case of Easter Island, some very recent and independent data from paleoecology and archaeology suggest a gradual, rather than sudden, ecological and social change. These data may have important implications for the nature (and the occurrence itself) of the paradigmatic socioecological collapse. First, a detailed paleoclimatic and paleoecological reconstruction of the last 3800 years showed that the replacement of palm forests by grass meadows was gradual and spanned more than 2000 years (Cañellas-Boltà et al., 2013). More recently, Mulrooney (2013) performed a spatial and temporal analysis on over 300 radiocarbon dates from archaeological sites across the island and did not find empirical support for a sudden and widespread abandonment of inland areas prior to European contact. Rather, chronological evidence shows continuity in settlement and landscape use during the entire cultural sequence from the period of initial island colonization to post-European contact. The fact that evidence of progressive changes comes from fields as distinct as paleoecology and archaeology strengthens interpretations of a gradual ecological shift. However, this fact also shows the current disconnection between these two disciplines. As part of a general call for mutual understanding among scholars from humanities and natural sciences (Förster et al., 2013), we emphasize the need to establish collaboration between 
researchers from disparate disciplines working on Easter Island (e.g., history, anthropology, archaeology, paleoecology, paleoclimatology, and others) to formulate more general hypotheses that may lead to more holistic views of island's history.

To promote interdisciplinary collaboration, we will summarize the existing paleoecological evidence for gradual ecological changes on Easter Island during the last few millennia. Archaeology/anthropology and paleoecology on Easter Island, as in many other areas (e.g., the Amazon Basin; Tollefson, 2013), have traditionally progressed as separate disciplines and the potential benefits of their interaction have not been fully exploited. Paleoecology may provide unique evidence to test hypotheses about causes (either natural or anthropic, or both) of an ecological shift, a landmark of Easter Island's history. To date, archaeological and anthropological research has rarely addressed the potential role of environmental changes, specifically climatic, as potential drivers for social transformations on the island. An advantage of paleoarchives, as for example lake sediments, is the possibility of obtaining continuous records for long time periods, thus minimizing the possibility of historical gaps. Conversely, paleoecologists and paleoclimatologists have been unable to capture the full extent and the implications of archaeological and anthropological evidence for paleoenvironmental reconstruction. We would like to use this particular case study to show how archaeology and paleoecology, working together, can notably enhance the scope and robustness of our understanding of ecological and human trends, which should be part of the same history. This paper is focused on the last few millennia and is subdivided into three main aspects in which paleoecology-archaeology synergies may be especially fruitful, as follows: (1) the initial settlement of the island, (2) the tempo and mode of the ensuing landscape transformations, and (3) the potential roles of climate, human activities, and climate-human synergies in environmental shifts. The particular points in which more archaeological evidence is needed are highlighted.

\section{THE FIRST SETTLERS: WHEN AND WHO}

The timing of arrival and the origin of the first colonizers are crucial aspects in properly understanding the ecological and human history of Easter Island. The more accepted dates of the first human arrival range from AD 800-1000 to AD 1200 (Hunt and Lipo, 2006; Vargas et al., 2006); however, there are some outliers that are worth mentioning. For example, Flenley and Bahn (2003) considered the island to have been colonized earlier, around AD 300, whereas Wilmshurst et al. (2011) proposed a later date between AD 1200 and AD 1290. An earlier date of approximately AD 50 (1900 cal y BP) was proposed based on palynological evidence (Flenley and Bahn, 2007; Butler and Flenley, 2010), but this suggestion used the hypothetical deforestation by humans as a premise and therefore employed somewhat circular reasoning (Rull et al., 2013).

More recent empirical evidence for human presence on the island is based on the appearance and the subsequent successful establishment of an introduced plant (Verbena litoralis, locally called "puringa"). This event occurred at approximately 450 BC and coincided with an increase in charcoal, the proxy for fire incidence (Figure 1). V. litoralis had been absent from the island

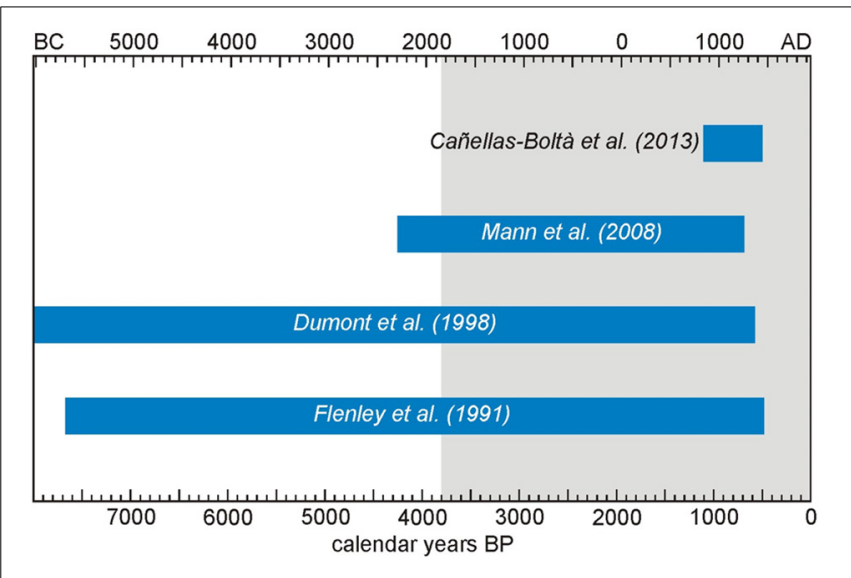

FIGURE 1 | Progressive reduction in the extent of the sedimentary gap (blue bars) on Lake Raraku sedimentary record. Radiocarbon ages from Flenley et al. (1991) and Dumont et al. (1998) have been calibrated with CALIB 6.0 (http://calib.qub.ac.uk/calib/). The gray area is the time interval covered by the study of Cañellas-Boltà et al. (2013), spanning the last $\sim 3700$ cal years BP and including most of the previously missing interval.

during the previous 34,000 years. This plant is known to be linked to human activities such as cultivation for medical purposes or as a ruderal weed. Therefore, its continuous occurrence and abundance since $450 \mathrm{BC}$ suggest human presence some 1500 years earlier than is commonly assumed (Cañellas-Boltà et al., 2013). Regarding the origin of the first settlers, genetic studies on prehistoric (pre-European contact) skeletal remains indicated that the original Easter Island inhabitants were Polynesian (Hagelberg et al., 1994). However, recent DNA analyses have suggested contributions from ancient Amerindians to the Easter Islanders' human gene pool (Thorsby, 2012), which suggests prehistoric contact between South America and Easter Island. According to this body of evidence, the human society of the island prior to the European arrival was likely primarily Polynesian in origin but may have contained some Amerindian genetic and cultural elements. The presence and expansion of $V$. litoralis, which is considered to be of American origin (Zizka, 1991; Wagner et al., 1999), reinforces the concept that Amerindian influence was present since the very beginning of the human presence on Easter Island.

All of these hypotheses, however, rely only on indirect paleoecological evidence and need to be tested with further archaeological and DNA analyses. For example, the finding of archaeological evidence (dwelling remains, tools, pottery, charcoal, and other manifestations of human activities) older than commonly accepted should not be dismissed under the new scenario discussed in this paper; rather, this type of evidence should be encouraged. Similarly, an intensive program of dating and DNA analyses on the available human remains would be helpful to unravel the antiquity and the origin of the first settlers. Recently, specific biomarkers of human origin, as for example lipids from fecal material, have been used as direct indicators of human presence (D'Anjou et al., 2012) and should be incorporated to Easter Island's research. 


\section{LANDSCAPE TRANSFORMATIONS: TIMING AND PACE}

The presumed ecological collapse was inferred mainly from a sudden change in the palynological record. This shift is interpreted as the island-wide replacement of palm-dominated forests by grasslands as a result of extensive human-mediated deforestation by AD 1000-1200 (Flenley et al., 1991; Mann et al., 2008). The scenario of a sudden forest demise has established itself as the prevailing view of the island's history, despite criticism from two main angles. First, it has been noted that the high percentages of palm pollen do not necessarily imply that the whole island was forested (Ritchie, 1995). Local forest stands surrounding the coring sites would have provided similar pollen assemblages, which are common within present-day tropical and sub-tropical palm stands (Rull et al., 2010). Second, the abruptness of change may be an artifact due to the existence of a sedimentary hiatus, disrupting the continuity of the record (Rull et al., 2013). For example, in the case of sediments from Lake Raraku, a lake near the quarry of the famous Rapanui stone statues or moais, this hiatus was initially thought to span from ca. 7000 to $500{ }^{14} \mathrm{C}$ y BP (Flenley and King, 1984; Flenley et al., 1991), but was later constrained to ca. $4200 \mathrm{cal}$ y BP to AD 1200 (Mann et al., 2008) (Figure 1). More recent studies have shed light on the tempo and mode of ecological shifts by finding more continuous sedimentary records that minimize the missing record (e.g., Butler and Flenley, 2010). However, a substantial part of the interval of interest, including the replacement of palm forests by grasslands, was still missing, which continued to make it difficult to know when and how (and possibly why) this ecological shift actually took place.

The most continuous record of the last millennia obtained so far is from Lake Raraku. This record encompasses the last $\sim 3700$ cal y BP, with a minor sedimentary gap of less than 700 years at the interval of interest (Cañellas-Boltà et al., 2013) (Figure 1). This gap represents a reduction of $80-90 \%$ in the missing interval with respect to previous works (Flenley et al., 1991; Mann et al., 2008; Sáez et al., 2009). As a result, it has become clear that the replacement of palm forests by grasslands took place in a gradual manner between approximately $500 \mathrm{BC}$ and AD 1500 (Figure 2). During these 2000 years, the forest decline and the progressive establishment of grasslands proceeded at a fairly constant rate (ca. 3\% reduction per century, in palm pollen units), with some minor accelerations. The onset of this replacement roughly coincided with the first appearance of $V$. litoralis (Figure 2), which has been used as indirect evidence for island colonization. Hence, it could be hypothesized that human activities played a role in the palm forest demise since initial colonization but in a gradual rather than catastrophic manner. This hypothesis is also supported by Mulrooney's (2013) evidence of continuous settlement and gradual landscape use.

\section{NATURAL AND ANTHROPIC DRIVERS OF ENVIRONMENTAL CHANGE}

The proponents of the socio-ecological collapse excluded natural climatic drivers as the cause of such an ecological collapse. Their main argument is that no equivalent palm-forest demise was recorded during the Last Glacial Maximum (ca. 21,000 y $\mathrm{BP}$ ), a period when the climate is known to have changed significantly worldwide, including Easter Island (Sáez et al., 2009;
Margalef et al., 2013). Therefore, it is improbable that the minor climatic variations of the last millennium could have caused the total replacement of palm forests by grass meadows, as observed in the palynological records (Azizi and Flenley, 2008). Some theoretical speculations exist about the potential role of recent climatic events, such as the Little Ice Age (LIA) or an intensification of ENSO variability (McCall, 1993; Nunn, 2000; Nunn and Britton, 2001), but so far, the required supporting evidence has not been provided for these proposals.

In the almost continuous Raraku sequence mentioned before, a variety of paleoenvironmental proxies independent of pollen were analyzed to infer paleoclimatic trends Cañellas-Boltà et al. (2013). A detailed explanation is provided in the original paper; here, only the more significant findings are shown. The most informative of these data were diatoms, proxies for aquatic environment types, and carbon to nitrogen $(\mathrm{C} / \mathrm{N})$ atomic ratios, indicators of the origin of organic matter. A shift from benthic to tychoplanktonic diatom dominance occurred around AD 1200 (Figure 2). This observation suggests a change from mire to shallow-lake conditions that are similar to the present state. The diatom shift is also paralleled by a sedimentary change from peat to silt deposition. $\mathrm{C} / \mathrm{N}$ values between 4 and 10 are typical of phytoplankton, whereas ratios of 20 and greater are more common in the cellulose-rich and protein-poor organic matter from land plants (Meyers and Teranes, 2001). Intermediate values indicate different degrees of mixing between these two sources. In our case, $\mathrm{C} / \mathrm{N}$ ratios typical from land plants prevail in the phase of lower lake levels and shift to intermediate values during the interval of higher lake levels, which supports the interpretation based on diatoms and sediment characteristics (Figure 2). As lake level oscillations are one of the more reliable indicators of variations in the hydrological balance (i.e., the precipitation/evapotranspiration ratio or $\mathrm{P} / \mathrm{E}$ ), Cañellas-Boltà et al. (2013) inferred a shift from drier to wetter climates at approximately AD 1200. This period is roughly coeval with a phase of rapid cooling and wetter conditions in the eastern Pacific Basin, which has been linked to an increase in the frequency of El Niño events (Nunn, 2007).

Interestingly, the onset of wetter climates coincided with an acceleration of palm demise and a significant increase in fire incidence (Figure 2). This combination strongly suggests increased vegetation disturbance by humans, likely favored by wetter conditions. Increased water availability would have favored agriculture and population growth thus boosting the exploitation of natural resources and the need for more cultivated land, leading to palm demise. So far, this interpretation is highly speculative, but it is possible that the moisture increase favored human population growth, resulting in increased landscape disturbance. Further historical and archaeological evidence is needed to test this hypothesis. Understanding the potential occurrence of climate-human feedbacks is crucial to a proper understanding of Easter Island's history. Another acceleration of palm demise, linked to a major peak of charcoal influx, occurred between AD 1400 and 1500 . However, in this case, biological and geological indicators show no significant change in climate, and therefore, the more likely causes might be related to social changes. 


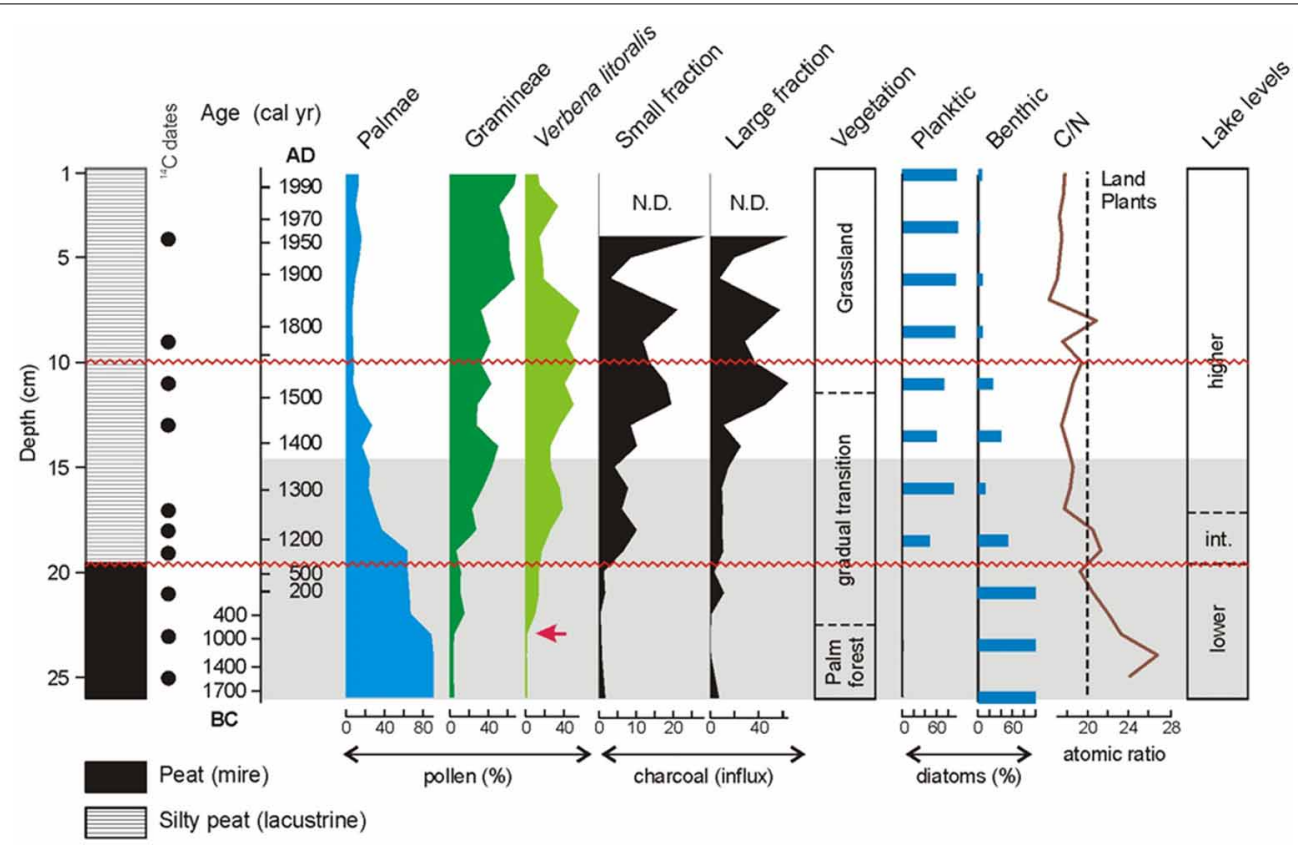

FIGURE 2 | Summary multiproxy diagram from Lake Raraku corresponding to the last $\sim \mathbf{3 7 0 0}$ years interpreted in terms of vegetation and lake-level (i.e., climatic). Charcoal influx was measured in particles $\mathrm{cm}^{-2}$ year $^{-1}$; the small fraction is considered to be representative of widespread fires while the large fraction reflects more local burning activities. The gray area is the interval missing in former surveys on Lake Raraku sediments (Flenley et al., 1991; Dumont et al., 1998; Mann et al., 2008). Note that some keystone events occurred during this interval; for example, the gradual replacement of palm-dominated forests by grasslands, the first appearance of Verbena litoralis (red arrow), the onset of charcoal deposition and the shift from drier to wetter climates. Adapted from Cañellas-Boltà et al. (2013).
Once more, historical and archaeological input is required to clarify this point. In this case, the straightforward interdisciplinary collaboration seems to be required from the beginning. A sound approach would be the development of join research programs including a wide array of past evidence (lake sediments, archaeological sites, documentary records, etc.) and proxies (physico-chemical indicators, remains of aquatic organisms, pollen, macrofossils, biomarkers, DNA, phytoliths, starch remains, charcoal, bones, artifacts, writings, etc.) in the search for more complete and robust reconstructions of the island's history. This type of integrated approaches have proven to be fruitful in other areas (Dearing et al., 2008).

\section{CONCLUSIONS AND FINAL REMARKS}

The available paleoecological evidence shows that Easter Island's landscape transformed gradually since the earliest human colonization of the island. The most notable of these transformations was the replacement of palm-dominated forests by grasslands. Our observations agree with Mulrooney's (2013) argument of gradual social change and challenge the current paradigm of a human-driven ecological catastrophe causing a social collapse around AD 1000-1200 or later. Both archaeological and paleoecological evidence point to a new view of Easter Island's history. To encourage interaction, we highlight a number of specific points in which collaboration between these disciplines is necessary to thoroughly test these hypotheses. The first concerns the initial colonization of the island. Recent paleoecological records suggest that landscape transformation by humans might have commenced $\sim 1500$ years earlier than formerly thought and that a more complex pattern for the origin of the first successful colonizers should be envisioned. If this idea is further confirmed by archaeological evidence, the interpretation of Easter Island's prehistory might need a thorough revision. Additionally, there is promising agreement between the gradual pace of ecological and social changes, as noted before. However, this line of research should be pursued further via both archaeological and paleoecological perspectives. The third point addresses the potential causes of landscape and social transformation. The role of either climate or human activities, or both, should be thoroughly investigated in each particular case. For example, we have suggested possible climate-human feedbacks as the cause for an acceleration in the deforestation occurring at approximately AD 1200, yet, later, there is an absence of climatic changes linked to a second forest retreat between AD 1400 and 1500. These and other enigmas of Easter Island may only be solved by coupled archaeologicalpaleoecological studies. Such collaboration will pave the way toward future advances in the understanding of the human and ecological history of Easter Island.

Integrated interdisciplinary research is needed not only to unraveling local historical trends but also to addressing global concerns. Human-environment interactions have been constant during the recent history and may determine the future trends of our planet. Therefore, transdisciplinarity is a necessity when addressing the potential consequences of global change, and to derive future possibilities from history (van der Leeuw et al., 2011; Dearing, 2013). 


\section{AUTHOR CONTRIBUTIONS}

All authors contributed equally to the work with ideas, interpretations, and discussions. Valentí Rull wrote the paper and the other authors revised the initial draft.

\section{ACKNOWLEDGMENTS}

This research was supported by projects LAVOLTER (CGL2004-00683/BTE), GEOBILA (CGL2007-60932/BTE) and CONSOLIDER GRACCIE (CSD2007-00067), from the Spanish Ministry of Science and Education.

\section{REFERENCES}

Azizi, G., and Flenley, J. R. (2008). The last glacial maximum climatic conditions on Easter Island. Quat. Int. 184, 166-176. doi: 10.1016/j.quaint.2007.09.027

Butler, K., and Flenley, J. R. (2010). The Rano Kau 2 pollen diagram: paleoecology revealed. Rapa Nui J. 24, 5-10.

Cañellas-Boltà, N., Rull, V., Sáez, A., Margalef, O., Bao, R., Pla-Rabes, S., et al. (2013). Vegetation changes and human settlement of Easter Island during the last millennia: a multiproxy study of the Lake Raraku sediments. Quat. Sci. Rev. 72, 36-48. doi: 10.1016/j.quascirev.2013.04.004

D’Anjou, R. M., Bradley, R. S., Balascio, N. L., and Finkelstein, D. B. (2012). Climate impacts on human settlement and agricultural activities in northern Norway revealed through sediment biogeochemistry. Proc. Natl. Acad. Sci. U.S.A. 109, 20332-20337. doi: 10.1073/pnas.1212730109

Dearing, J. A. (2013). Why future earth needs lake sediment studies. J. Paleolimnol. 49, 537-545. doi: 10.1007/s10933-013-9690-1

Dearing, J. A., Jones, R. T., Shen, J., Yang, X., Boyle, J. F., Foster, G. C., et al. (2008). Using multiple archives to understand past and present climate-humanenvironment interactions: the lake Erhai catchment, Yunnan Proovince, China. J. Paleolimnol. 40, 3-31. doi: 10.1007/s10933-007-9182-2

Diamond, J. M. (2005). Collapse: How Societies Choose to Fail or Succeed. New York, NY: Viking.

Dumont, H. J., Cocquyt, C., Fontugne, M., Arnold, M., Reyss, J. L., Bloemendal, J., et al. (1998). The end of moai quarrying and its effects on Lake Rano Raraku, Easter Island. J. Paleolimnol. 20, 409-422. doi: 10.1023/A:1008012720960

Etienne, M., Michea, G., and Díaz, E. (1982). Flora, Vegetación y Potencial Pastoral de la Isla de Pascua. Boletín Técnico ${ }^{\circ} 47$ (Santiago: Univ. de Chile).

Flenley, J. R., and Bahn, P. G. (2003). The Enigmas of Easter Island. Oxford: Oxford University Press.

Flenley, J. R., and Bahn, P. G. (2007). Conflicting views of Easter Island. Rapa Nui J. 21, 11-13.

Flenley, J. R., and King, S. M. (1984). Late quaternary pollen records from Easter Island. Nature 307, 47-50. doi: 10.1038/307047a0

Flenley, J. R., King, S. M., Jackson, J., Chew, C., Teller, J. T., and Prentice, M. E. (1991). The late quaternary vegetational and climatic history of Easter Island. J. Quat. Sci. 6, 85-115. doi: 10.1002/jqs.3390060202

Förster, F., Grossmann, R., Hinz, M., Iwe, K., Kinkel, H., Larsen, A., et al. (2013). Towards mutual understanding within interdisciplinary palaeoenvironmental research: an exemplary analysis of the term landscape. Quat. Int. 312, 4-11. doi: 10.1016/j.quaint.2013.07.045

Hagelberg, E., Quevedo, S., Turbon, D., and Clegg, J. B. (1994). DNA from ancient Easter Islanders. Nature 369, 25-26. doi: 10.1038/369025a0

Hunt, T. L., and Lipo, C. P. (2006). Late colonization of Easter island. Science 311, 1603-1606. doi: 10.1126/science.1121879

Hunt, T. L., and Lipo, C. P. (2010). "Ecological catastrophe, collapse, and the myth of 'ecocide' on Rapa Nui (Easter Island)," in Questioning Collapse, eds P. A. McAnany and N. Yoffee (Cambridge: Cambridge University Press), 21-44.

Mann, D., Edwards, J., Chase, J., Beck, W., Reanier, R., Mass, M., et al. (2008). Drought, vegetation change, and human history on Rapa Nui (Isla de Pascua, Easter Island). Quat. Res. 69, 16-28. doi: 10.1016/j.yqres.2007.10.009

Margalef, O., Cañellas-Boltà, N., Pla-Rabes, S., Giralt, S., Pueyo, J. J., Joosten, H., et al. (2013). A 70,000 year multiproxy record of climatic and environmental change from Rano Aroi (Easter Island). Glob. Planet. Change 108, 72-84. doi: 10.1016/j.gloplacha.2013.05.016

McCall, G. (1993). Little Ice Age, some speculations for Rapanui. Rapa Nui J. 7, 65-70.
Meyers, P. A., and Teranes, J. L. (2001). "Sedimentary organic matter," in Traking Environmental Changes Using Lake Sediements, Volume 2: Physical and Geochemical Methods, eds W. M. Last and J. P. Smol (Dordrecht: Kluwer), 239-269.

Mulrooney, M. H. (2013). An island-wide assessment of the chronology of settlement and land use on Rapa Nui (Easter Island) based on radiocarbon data. J. Archaeol. Sci. 40, 4377-4399. doi: 10.1016/j.jas.2013.06.020

Nunn, P. D. (2000). Environmental catastrophe in the Pacific Islands around A.D. 1300. Geoarchaeology 15, 715-740. doi: 10.1002/15206548(200010)15:7<715::AID-GEA4>3.0.CO;2-L

Nunn, P. D. (2007). Climate, Environment and Society in the Pacific During the Last Millennium. Amsterdam: Elsevier.

Nunn, P. D., and Britton, J. M. R. (2001). Human-environment relationships in the Pacific, Islands around A.D. 1300. Environ. Hist. 7, 3-22. doi: 10.3197/096734001129342388

Ritchie, J. C. (1995). Current trends in studies of long-term plant community dynamics. New Phytol. 130, 469-494. doi: 10.1111/j.1469-8137.1995. tb04325.x

Rull, V., Cañellas-Boltà, N., Sáez, A., Giralt, S., Pla, S., and Margalef, O. (2010). Paleoecology of Easter Island: evidence and uncertainties. Earth Sci. Rev. 99, 50-60. doi: 10.1016/j.earscirev.2010.02.003

Rull, V., Cañellas-Boltà, N., Sáez, A., Giralt, S., Pla-Rabes, S., and Margalef, O. (2013). "Paleoecology and human history of Easter Island (southern Pacific Ocean): some problems and potential solutions," in Proceedings of Palaeoenvironment and the Development of Early Societies (Berlin: German Archaeological Institute).

Sáez, A., Valero-Garcés, B. L., Giralt, S., Moreno, A., Bao, R., Pueyo, J. J., et al. (2009). Glacial to Holocene climate changes in the SE Pacific. The Raraku lake sedimentary record (Easter Island, $27^{\circ}$ S). Quat. Sci. Rev. 28, 2743-2759. doi: 10.1016/j.quascirev.2009.06.018

Thorsby, E. (2012). The Polynesian gene pool: an early contribution by Amerindians to Easter Island. Philos. Trans. R. Soc. B 367, 812-819. doi: 10.1098/rstb.2011.0319

Tollefson, J. (2013). Footprints in the forest. Nature 502, 160-162. doi: $10.1038 / 502160 \mathrm{a}$

van der Leeuw, S., Costanza, R., Aulenbach, S., Brewer, S., Burek, M., Cornall, A., et al. (2011). Toward in integrated history to guide the future. Ecol. Soc. 16, 2. doi: 10.5751/ES-04341-160402

Vargas, P., Cristino, C., and Izaurieta, R. (2006). 1000 años en Rapa Nui. Arqueología del Asentamiento. Santiago: Ed. Universitaria.

Wagner, W. L., Herbst, D. R., and Sohmer, S. H. (1999). Manual of the Flowering Plants of Hawaii. Honolulu, HI: Bernice P. Bishop Museum.

Wilmshurst, J. M., Hunt, T. L., Lipo, C. P., and Anderson, A. J. (2011). Highprecision radiocarbon dating shows recent and rapid initial human colonization of East Polynesia. Proc. Natl. Acad. Sci. U.S.A. 108, 1815-1820. doi: 10.1073/pnas.1015876108

Zizka, G. (1991). Flowering Plants of Easter Island. Frankfurt: Palmarum Hortus Francofurtensis.

Conflict of Interest Statement: The authors declare that the research was conducted in the absence of any commercial or financial relationships that could be construed as a potential conflict of interest.

Received: 27 October 2013; accepted: 30 November 2013; published online: 17 December 2013.

Citation: Rull V, Cañellas-Boltà N, Sáez A, Margalef O, Bao R, Pla-Rabes S, Valero-Garcés B and Giralt S (2013) Challenging Easter Island's collapse: the need for interdisciplinary synergies. Front. Ecol. Evol. 1:3. doi: 10.3389/fevo.2013.00003 This article was submitted to Paleoecology, a section of the journal Frontiers in Ecology and Evolution.

Copyright (c) 2013 Rull, Cañellas-Boltà, Sáez, Margalef, Bao, Pla-Rabes, Valero-Garcés and Giralt. This is an open-access article distributed under the terms of the Creative Commons Attribution License (CC BY). The use, distribution or reproduction in other forums is permitted, provided the original author(s) or licensor are credited and that the original publication in this journal is cited, in accordance with accepted academic practice. No use, distribution or reproduction is permitted which does not comply with these terms. 